\title{
Cidades-empresa numa cadeia produtiva transnacional: dimensões sociais e ambientais da produção de alumínio em Porto Trombetas, Brasil, e Årdal, Noruega*
}

Frank Meyer**

Resumo: Este artigo discute o impacto da produção de alumínio nas comunidades de Porto Trombetas, localizadas no estado do Pará, e em Årdal, na Noruega. O artigo tem como foco principal a comparação entre condições de trabalho desses dois grupos de trabalhadores, considerando também o impacto social e ambiental dessa cadeia produtiva transnacional. No Brasil, este estudo analisa, em particular, as relações de trabalho no setor do alumínio durante o período da ditadura militar. Acredita-se que a natureza da produção, assim como as características das comunidades locais e o contexto político e social de diferentes países, propiciem análises comparativas interessantes que apontam diferenças e similaridades entre as cidades-empresa (company towns).

Palavras-chave: alumínio; cadeia produtiva internacional; meio-ambiente.

\begin{abstract}
In this article the impacts of aluminum production on the local populations at two sites of production are discussed - Porto Trombetas (Brazil) and Årdal (Norway). The main focus of the comparison is on the living and working conditions of the local populations, and on the social and ecological impacts of their incorporation into the transnational commodity chain. The nature of production, the characteristics of local communities and the socio-political context in the different countries have contributed to creating interesting similarities and differences in the development of these entangled company towns.
\end{abstract}

Keywords: aluminium; transnational commodity chain; environment.

* Publicado originalmente em BORGES, Marcelo e TORRES, Suzana (orgs.). Company Towns: Labor, Space, and Power Relations across Time and Continents. Nova York: Palgrave Macmillan, 2012, p. 181-195. Tradução de Irene Portela. O autor agradece ao Prof. Michael Seltzer e a Thais de Araújo Ferraz pelas sugestões que ajudaram a melhorar este artigo.

** Frank Meyer foi professor da área de Estudos Multiculturais na Oslo University College, durante os anos de 2003 e 2012. Desde 2011 é diretor do Arquivo e Biblioteca do Movimento Operário Norueguês. E-mail: frank. meyer@arbark.no. 
Milhares de quilômetros e uma profunda diversidade de ambientes geográficos separam Porto Trombetas e Årdal. Todavia, desde meados da década de 1970, as duas cidades estão ligadas por uma cadeia produtiva transnacional. Por mais de 35 anos os trabalhadores das minas na Amazônia brasileira escavaram bauxita dos depósitos do rio Trombetas e carregaram o minério em navios graneleiros para serem levados às várias refinarias e transformados em óxido de alumínio. Um destes lugares é a cidade norueguesa de Årdal, localizada no interior do Sognefjord, que ao longo do século XX transformouse num importante centro industrial e em meados do século tornou-se a sede da maior usina de alumínio da Europa Ocidental. Inicialmente sugerida por Terence Hopkins e Immanuel Wallerstein, a expressão "cadeia produtiva" descreve "uma rede de processos de trabalho e produção cujo resultado é uma mercadoria final". ${ }^{1}$ Por seu turno, rede global de uma mercadoria "consiste numa série de redes interorganizacionais centradas numa mercadoria no âmbito da economia mundial", que é "situacionalmente específica, socialmente construída e localmente integrada, e que evidencia o preenchimento da organização econômica pelo social". ${ }^{2}$ Nos extremos opostos da cadeia produtiva global do alumínio, as cidades-empresa Porto Trombetas e Årdal são exemplo de adaptações locais.

Este artigo analisa as condições de vida e trabalho em ambas as cidades e os impactos sociais e ambientais de sua incorporação na cadeia produtiva. ${ }^{3}$ A natureza da produção, as características das comunidades locais e o contexto sociopolítico em ambos os países deram origem tanto a semelhanças como a diferenças no desenvolvimento destas duas cidades-empresa. Nos dois lugares, esse processo de incorporação envolveu o Estado, corporações nacionais e internacionais, populações locais e trabalhadores migrantes. Este artigo também considera a interação entre esses atores e o impacto da mudança nas condições sociopolíticas no desenvolvimento das duas comunidades.

Porto Trombetas e Årdal evoluíram de modos diferentes. Porto Trombetas pode ser caracterizada como um enclave mineiro que se desenvolveu a partir de um campo de trabalho, ao passo que Årdal apresenta-se como uma comunidade de uma única empresa, que cresceu a partir de um vilarejo preexistente ligado à agricultura e à pesca. A área onde a cidade-empresa de Porto Trombetas se estabeleceu era bem menos povoada e mais isolada do mundo externo do que Årdal. As comunidades ribeirinhas do Rio Trombetas baseavam-se na pesca, coleta e caça para consumo, com pouca ligação com grupos de fora da área. De modo análogo a cidades-empresa em outras periferias produtoras de recursos, em Porto Trombetas a empresa mineradora construiu a cidade e proveu alojamento e serviços para os seus trabalhadores, que foram recrutados em outras regiões. ${ }^{4}$

1 HOPKINS, Terence e WALLERSTEIN, Immanuel. Commodity Chains in the World Economy Prior to 1800. Review, Fernand Braudel Center, vol. 10, n 1, p. 159, 1986. Marcel van der Linden lembrou-nos do termo francês filière, usado na década de 1960, que antecipava elementos chave da abordagem da cadeia produtiva. Ver: VAN DER LINDEN, Marcel. Globalizing Labour Historiography: The IISH Approach. Amsterdam: International Institute of Social History, 2002, disponível em: www.iisg.nl/publications/globlab/pdf.

2 GEREFFI, Gary, KORZENIEWICZ, Miguel e KORZENIEWICZ, Roberto. Introduction: Global Commodity Chains. In: GEREFFI, Gary, KORZENIEWICZ, Miguel e KORZENIEWICZ, Roberto (Eds.). Commodity Chains and Global Capitalism. Westport (CT). Greenwood, 1994, p. 2. Ver também Bunker, Stephen e CICCANTELL, Paul. Globalization and the Race for Resources. Baltimore, MD: Johns Hopkins University Press, 2005.

3 HALL, Thomas. Incorporation in the World-System: Toward a Critique. American Sociological Review, vol. $51, n^{\circ} 3$, p. 390-402, 1986.

4 Para outros casos, ver as análises de cidades-empresa na Argentina, Canadá e Indonésia em BORGES e TORRES. Company Towns. Para uma experiência brasileira nos mesmos moldes, vide o exemplo da 'Fordlândia' de Henry Ford em GRANDIN, Greg. Fordlandia. The Rise and Fall of Henry Ford's Forgotten Jungle 
Na área de Årdal, havia comunidades estabelecidas antes da industrialização, que constituíam uma fonte de mão de obra. Trabalhadores adicionais foram recrutados essencialmente na região. Esta foi a situação mais comum no tocante à maioria das cidades-empresa na Noruega. ${ }^{5}$

Em contraste com Porto Trombetas, em Årdal o papel da empresa como provedora de habitação para seus trabalhadores - um dos aspectos definidores das cidades-empresa - restringiu-se a períodos limitados de incremento na atividade econômica associados a um aumento significativo na chegada de novos trabalhadores. A presença da indústria de alumínio tornou-se um fator dominante, mas nunca exclusivo. Mais isolada e dependente de uma única companhia, Porto Trombetas tinha menor autonomia diante dos interesses da empresa em comparação com Årdal. Por último, a presença regulatória do Estado ocorreu de forma diferente no Brasil e na Noruega, com efeitos nas relações de trabalho e em termos dos impactos das atividades de mineração e industriais no meio ambiente. Porto Trombetas foi criada na década de 1970, quando o Brasil era governado por uma ditadura militar. Por seu turno, o desenvolvimento de Årdal começou muito antes, e a fábrica de alumínio foi construída durante os cinco anos de ocupação militar alemã na Noruega, iniciada em 1940. Em ambos os lugares, o ritmo e a intensidade do desenvolvimento industrial foram muito elevados nessa época. Durante governos democráticos - na Noruega desde 1945 e no Brasil desde 1985 - o papel do Estado foi mais ativo no tocante tanto às relações de trabalho como ao meio ambiente.

Estes estudos de caso mostram as consequências de um desenvolvimento desigual numa época de conectividade global - que se caracteriza por redes de alcance global através das quais as mercadorias são produzidas utilizando elementos oriundos de diversos continentes. ${ }^{6} \mathrm{~A}$ cadeia produtiva transnacional conectando Porto Trombetas e Årdal foi criada e administrada por meia dúzia de empresas. A composição do conglomerado de acionistas da mina e da usina de alumínio sofreu alterações ao longo do tempo, mas podemos elencar três tipos de laços empresariais conectando Porto Trombetas e Årdal. Entre 1974 e 1979, a usina de alumínio de Årdal ( ̊̊SV) detinha 5\% das ações da mina. Sobrepondo-se em parte à presença da ÅSV no Brasil, entre 1966 e 1986, a multinacional canadense Alcan detinha ações tanto na mina (12 a 19\%) como na usina de alumínio (50\% até 1969 e $25 \%$ entre 1969-86). Por fim, a Norsk Hydro AS era detentora de $5 \%$ das ações da mina desde 1974 - direta ou indiretamente, através de uma empresa subsidiária brasileira - e comprou a usina de alumínio da Årdal em 1986. 7 Nos anos iniciais da mineração, a produção de bauxita era inteiramente absorvida pelas empresas estrangeiras. Em função das políticas do governo brasileiro de industrialização baseada no modelo de substituição de importações nas décadas de 1970 e 1980, uma parte crescente da bauxita começou a ser processada no Brasil e utilizada por indústrias brasileiras. ${ }^{8}$ Em 2008, 60\% da bauxita extraída

City. Nova York: Metropolitan Books, 2009.

5 KJELDSTADLI, Knut. Lokal Internasjonalism. In: AMDAM, Rolv Petter, GJESTLAND, Dag e HOMPLAND, Andreas (orgs.). Årdal: Verket og bygda 1947-1997. Oslo: Det norske samlaget, 1997, p. 38-55. KJELDSTADLI, Knut. Å komme, å bli, å bygge. In: FOSSÅSKÅRET, Erik e Frode STORÅS (Eds.). Ferro-folket ved fiorden. Historien om Bjølvefossen i Hardanger. Bergen e Ålvik: Nord 4, 1999, p. 48-80.

6 VAN DER LINDEN, Marcel. Sattelzeit. Strategien von oben, Lernprozesse von unten. In: VAN DER LINDEN, Marcel e LIEBER, Christoph (orgs.). Kontroversen über den Zustand der Welt: Weltmarkt. Arbeitsformen. Hegemoniezyklen. Hamburg: VSA, 2007, p. 25.

7 DE SIQUEIRA, Ozair Pereira. Mineração Rio do Norte Tells its Story from the Beginning. Porto Trombetas. MRN, 2002, p. 38-9, 181; http://www.hydro.com/no/Pressesenter/Nyheter/Arkiv/2002/Mai/15888.

8 HILDEBRAND, Lars. Die globale Güterkette der Aluminiumindustrie: Weltmarktintegration als 
em Porto Trombetas era processada em refinarias e fundições no Nordeste do Brasil. 9

\section{Porto Trombetas: uma cidade-empresa na Amazônia, antes da bauxita}

Localizada no nordeste do estado do Pará, $880 \mathrm{~km}$ a oeste de Belém e $400 \mathrm{~km}$ de Manaus, no rio Trombetas, a área que mais tarde se tornou o local da cidade-empresa de Porto Trombetas era conhecida como Sítio Conceição. A foz do rio Trombetas fica nas montanhas da Guiana. Deságua no rio Amazonas ligeiramente ao norte da cidade de Óbidos, no estado do Pará. Tem correntes muito intensas e quedas-d'água no seu curso superior; todavia, $200 \mathrm{~km}$ a partir de sua foz e ao norte, o rio é navegável. Por essa parte do rio e mais adiante, já no rio Amazonas, o Trombetas conecta-se à economia global através da mineração para exportação. ${ }^{10}$ A história oficial da empresa afirma que antes da Mineração Rio do Norte construir sua operação mineradora "nada jamais existira a não ser a floresta", onde "uma infraestrutura urbana e operativa [foi] implementada de modo a permitir a produção de bauxita". "Antes do estabelecimento da cidadeempresa de Porto Trombetas, contudo, uma população mista habitava a área, constituída por comunidades nativas e descendentes de escravos africanos fugitivos ou libertos da Guiana, do Suriname e da Venezuela, conhecidas como comunidades quilombolas.

Evidência arqueológica indica ter havido povoados de comunidades indígenas Conduri desde 205 a.C. até o período pós-colombiano na região entre o Baixo Trombetas e o Lago Faro. Após a ocupação portuguesa, estas comunidades foram impelidas cada vez mais em direção a suas regiões de origem no interior e estabeleceram-se nas margens do rio Trombetas. Entre os séculos XVI e XVII, a área do rio era chamada Cahu e habitada pelos indígenas Kaxuyana (ou Prehno). Estes grupos, como várias populações nativas sul-americanas, foram quase eliminados por doenças trazidas pelos recém-chegados. Para além disso, conflitos violentos entre os diferentes grupos indígenas levaram a um decréscimo na população. No final do século XIX, os remanescentes agruparam-se, num esforço de sobrevivência. ${ }^{2}$ Em 1960, apenas um dos diversos grupos da comunidade Kaxuyana vivia num raio de $100 \mathrm{~km}$ a partir de onde a mina foi aberta. A população declinara de aproximadamente 500 pessoas na década de 1920 para cerca de 60 na década de 1960. Para prevenir a extinção completa, o governo brasileiro realocou os sobreviventes $500 \mathrm{~km}$ ao norte, perto da fronteira com o Suriname, onde se juntaram a outra comunidade indígena, os Tirio. ${ }^{13}$

O segundo grupo étnico que vivia nas margens do rio Trombetas consistia

Entwicklungsstrategie? Erfahrungen aus Brasilien. Hamburg: Universität Hamburg. Institut für Geographie, 2007, p. 73-126.

9 INSTITUTO OBSERVATÓRIO SOCIAL e DEUTSCHER GEWERKSCHAFTSBUND BILDUNGSWERK (org.). Study of Aluminium Production Chain in Northern Brazil. São Paulo. Instituto Observatório Social, 2008.

10 DE Siqueira. Mineração Rio do Norte, p. 29-31. http://www.mrn.com.br/english/quem_somos/portotrombetas.html.

11 DE SIQUEIRA. Mineração Rio do Norte, p. 29 e 19.

12 Idem, p. 32.

13 AKER $\varnothing$, Dan Børge, BORGE, Per Erik, HVEEM, Helge e POLESZYNSKI, Dag. Norge i Brasil: Militærdiktatur, folkemord og norsk aluminium. Oslo: Aschehoug, 1979, p. 21-2. http:/www.pib.socioambiental.org/en/ povo/kaxuyana. 
em algumas centenas de famílias de comunidades quilombolas. A origem dessas comunidades, no Trombetas, não é muito clara. As famílias afirmam ser descendentes de escravos fugitivos ou libertos, representantes, pois, de uma conexão internacional mais antiga. ${ }^{14}$ Os contatos com povos indígenas das proximidades eram, todavia, comuns e é provável que os escravos fugitivos tenham espalhado doenças contagiosas que contribuíram para o declínio demográfico dos Kaxuyana. Ao longo do tempo, as comunidades quilombolas envolveram-se numa economia de troca com o mundo externo: de tabaco e frutos da floresta por café, açúcar, ferramentas e tecidos. ${ }^{15}$ De forma análoga às comunidades indígenas próximas, a economia dos quilombos baseava-se primordialmente na pesca, caça e coleta de castanhas-do-pará e bananas. Também cultivavam alguma canade-açúcar, café, açúcar, mandioca e vegetais. As comunidades locais produziam apenas para autoconsumo e as famílias mudavam-se com frequência em busca de alimentos. ${ }^{16}$

\section{Mineração e a construção da cidade-empresa}

Porto Trombetas teve vários estágios de desenvolvimento, da prospecção inicial à produção plena. O crescimento da cidade-empresa acompanhou estas fases sucessivas. Na fase inicial (1961-67), a multinacional de alumínio canadense Alcan utilizou um pequeno grupo de geólogos, engenheiros de minas e alguns trabalhadores locais para sondar na selva, na região do Trombetas, a existência de depósitos de bauxita. Na época, a Alcan estava interessada em encontrar uma substituta para a matéria-prima que era obtida de minas na Jamaica e na Guiné. Além disso, a recém-independente ex-colônia britânica Guiana ameaçava o controle que a Alcan há muito detinha sobre as minas de bauxita da Guiana, um estímulo adicional para expandir a produção de bauxita na Amazônia. ${ }^{17} \mathrm{O}$ grupo estabeleceu sua base no barco fluvial "Gaivota", ancorado na pequena comunidade ribeirinha de Terra Santa, no rio Amazonas. Explorando a área por barco e a pé, estabeleceram vários acampamentos até 1965, quando um acampamento no planalto de Saracá tornou-se a base das atividades mineradoras iniciais. O pessoal trabalhava na área em turnos de 90 dias, enfrentando clima úmido, insetos, animais selvagens e isolamento. ${ }^{18} \mathrm{Em} \mathrm{1967}$, análises laboratoriais confirmaram a existência de vastos depósitos de bauxita na área.

Nessa época, companhias estrangeiras de mineração não eram autorizadas a deter parcelas de terra com mais de 500 hectares. Por causa da pressão de várias empresas multinacionais, inclusive a U.S. Steel, esta limitação foi abolida

14 PRICE, Richard. Scrapping Maroon History. Brazil's Promise, Suriname's Shame. New West Indian Guide/ Nieuwe West-Indische Gids, vol. 72, n 3 e 4, p. 233-55, 1998. Gomes, Flávio dos Santos e Gledhill, Sabrina. A 'Safe Haven'. Runaway Slaves, Mocambos, and Borders in Colonial Amazon, Brazil. Hispanic American Historical Review, vol. 82, n³, p. 469-98, 2002.

15 SLATER, Candace. Entangled Edens: Visions of the Amazon. Berkeley: University of California Press, 2002, p. 161.

16 ANDRADE, Lucia M. M. The Quilombos of the Trombetas River Basin: Brief History. São Paulo: Comissão Pro-Índio, 1993. SLATER. Entangled Edens, p. 161; BUNKER, Stephen. Underdeveloping the Amazon: Extraction, Unequal Exchange, and the Failure of the Modern State. Urbana. University of Illinois Press, 1985. Por vezes, algumas pessoas dos povos indígenas ribeirinhos trabalhavam numa fazenda local de castanha-do-pará, perto de Oriximiná e Óbidos, na confluência do rio Trombetas.

17 DE SIQUEIRA. Mineração Rio do Norte, p. 19; Åkerø et al. Norge i Brasil., p. 158. Ver também BOULANGÉ, B. e CARVALHO, A. The Bauxite of Porto Trombetas. In: CARVALHO, A. et al (orgs.). Brazilian Bauxites. São Paulo e Paris. USP/FAPESP/ORSTOM, 1997.

18 DE SIQUEIRA. Mineração Rio do Norte, p. 18-25. 
por meio das mudanças na legislação brasileira em 1968 e 1969. Com isso, ficavam isentas empresas que operavam em áreas assim chamadas difíceis, tais como a região amazônica. No final de 1969, a Alcan adquiriu ou recebeu autorizações de prospecção prioritária em 63.000 hectares. ${ }^{19} \mathrm{Em} \mathrm{1970}$, a base em Terra Santa foi transferida para o Sítio Conceição e foi dado início à construção de um porto e de um pequeno aeroporto. Uma força de trabalho de 550 homens e máquinas foi transportada por avião para derrubar a floresta e começar a construção da base, da ferrovia, do porto e das instalações, completadas em maio de $1972 .{ }^{20}$

Umaterceirafase teveinício emmaio de1972, quandoaAlcantemporariamente interrompeu o projeto por causa da queda nos preços do alumínio. Iniciaram-se então negociações para recomeçar o projeto sob uma nova estrutura. Em 11 de junho de 1974, duas empresas brasileiras e sete estrangeiras acordaram explorar o depósito de bauxita do Trombetas sob a forma de uma joint venture, com $51 \%$ de participação de acionistas nacionais. Sob o nome Mineração Rio do Norte (MRN), a mina de Trombetas tornou-se parte do programa do governo Polamazônia, que visava ao desenvolvimento da Amazônia através do fortalecimento de centros urbanos, do incremento à navegação fluvial e do apoio à exploração de bauxita e de outras atividades. Em outubro de 1974, a agência governamental para o desenvolvimento da Amazônia, a SUDAM, aprovou uma isenção de dez anos no pagamento de impostos para o projeto de mineração. Além disso, o governo brasileiro garantiu seu financiamento. ${ }^{21}$

A quarta e última fase começou em 1977 e caracterizou-se pela implementação do projeto. Terminou em 1979, quando o primeiro carregamento de bauxita foi embarcado no porto de Trombetas. Neste período, áreas ainda maiores foram desflorestadas e deu-se início à construção da infraestrutura - instalações industriais para trituração, beneficiamento e carregamento; reservatórios de água e óleo; uma ferrovia de $30 \mathrm{~km}$ entre a mina e o porto; uma pista de pouso e decolagem de 1.250 metros de comprimento para pequenas aeronaves; um terminal para bauxita; uma central elétrica; e um porto de águas profundas com cais e guindastes de carregamento..$^{22} \mathrm{Em}$ 1979, a mina estava produzindo 3,35 milhões de toneladas de bauxita. Em 2001, o Brasil era o terceiro maior produtor mundial de bauxita, com 13,2 milhões de toneladas por ano. A mina de Porto Trombetas contribuía com aproximadamente $81 \%$ deste total (por volta de 10,7 milhões de toneladas por ano). ${ }^{23}$

Porto Trombetas passou de um campo de mineração a cidade-empresa ao longo de vários anos. A infraestrutura e as condições de moradia evoluíram pouco a pouco, acompanhando a expansão da produção. Nos primeiros anos, foi dada prioridade ao desenvolvimento das instalações técnicas e só existia o acampamento dos geólogos. Centenas de trabalhadores tinham que se deslocar duas horas por dia, de barco, de Cachoeira Porteira, um vilarejo que crescera quando da construção da Rodovia Norte Amazônica, para o local da obra. Além

19 Idem, p. 29. Ver também ÅKERØ et al. Norge i Brasil, p. 28. DAVIS, Shelton. Victims of the Miracle: Development and the Indians of Brazil. Cambridge: Cambridge University Press, 1977, p. 33-6.

20 DE SIQUEIRA. Mineração Rio do Norte, p. 35. PINTO, Lúcio Flávio. Amazônia: O século perdido: a batalha do alumínio e outras derrotas da globalização. Belém: Edição Jornal Pessoal, 1997, p. 89.

21 LÓPEZ, Alexander. Environmental Change, Social Conflicts and Security in the Brazilian Amazon: Exploring the Links. Oslo: Department of Political Science. University of Oslo, 2000. BUNKER. Underdeveloping the Amazon. BUNKER e CICCANTELL. Globalization and the Race for Resources, p. 33-77. ÅKER $\varnothing$ et al. Norge i Brasil, p. 160; DE SIQUEIRA. Mineração Rio do Norte, p. 25, 40; SLATER. Entangled Edens, p. 162.

22 DE SIQUEIRA. Mineração Rio do Norte, p. 69.

23 GIRNDT, Cornelia. Bergbau in Brasilien. Die Bauxitmine von Porto Trombetas. Quetza, Politik und Kultur in Lateinamerika, p. 1, 2008. 
disso, havia ligação regular por balsa com Santarém (uma viagem de barco de 15 a 20 horas). Quando a construção estava no auge, o número de barcos e chatas carregando tanto passageiros como carga chegava a 14, e até a 21, por dia. ${ }^{24}$ Os deslocamentos diminuíram à medida que os alojamentos eram construídos.

Nos primeiros anos, as casas eram itens escassos e objeto de disputas. De início, foram levantados 24 pavilhões de PVC e madeira, perto da zona industrial, para albergar mais de 6.000 trabalhadores. Ao cabo de algum tempo, seis tipos de casa padrão estavam disponíveis, cada um refletindo, no tamanho e grau de conforto, a estratificação social vigente na cidade-empresa. Para o grupo em posição mais elevada, os engenheiros sêniores, havia 11 casas de $278 \mathrm{~m}^{2}$; para os engenheiros juniores e para o pessoal com nível universitário ou equivalente, havia 196 casas com 197 m² os técnicos foram alocados em 80 casas com $82 \mathrm{~m}^{2}$; e os trabalhadores especializados em 120 casas com $70 \mathrm{~m}^{2}$. Além disso, existiam 400 casas pré-fabricadas e pavilhões para os trabalhadores não especializados.

Como ilustrado em análises de cidades-empresa deste porte na Alemanha, em Angola, na Argentina e no Canadá, tal distribuição hierárquica de casas por parte da empresa acompanhava práticas firmemente estabelecidas. A empresa cobrava apenas um aluguel simbólico. ${ }^{25}$ Todavia, um grupo de 70 trabalhadores que não tinha casa em Porto Trombetas vivia na cidade satélite de Carnã, descrita por pesquisadores na década de 1970 como um lugar de "caixas disformes", feitas de "pranchas, placas de estanho e papelão", onde os desempregados se estabeleciam com esperança de uma vida melhor perto do centro industrial emergente. ${ }^{26}$ Quando o trabalho de construção terminou, no final da década de 1970, a maior parte dos trabalhadores originais foi demitida e a demanda por moradia caiu correspondentemente. ${ }^{27} \mathrm{Um}$ núcleo de pessoal qualificado permaneceu no local e novos empregados foram recrutados de outras áreas do Brasil. ${ }^{28}$

Durante o período de implementação do projeto, as condições de trabalho e de vida eram duras para a maioria dos empregados, que trabalhavam 10 a 15 horas por dia, sete dias por semana. O tempo livre era limitado e nesse início a cidade-empresa não oferecia atividades de lazer. Muitos empregados procuravam distração na cidade satélite mais próxima, a qual, apesar de suas limitações, oferecia algumas atividades e um descanso da vigilância da empresa. ${ }^{29}$ A vida na vila residencial da empresa era altamente controlada, não apenas em termos de lazer, mas também da organização dos trabalhadores. Não se tolerava sindicatos (afora organizações de técnicos e engenheiros), e os trabalhadores não dispunham de contratos. Assim, com frequência recebiam menos do que fora acertado antecipadamente e eram forçados a trabalhar em níveis abaixo de suas qualificações.

Os alojamentos onde 4.000 a 5.000 trabalhadores dormiam em quartos com seis a oito trabalhadores em média eram cercados por arame farpado. A comida era de má qualidade e as filas longas. Não é, pois, de surpreender que o moral fosse

24 Idem, p. 72; PINTO, Lúcio Flávio. Amazônia: o século perdido.

25 DE SIQUEIRA. Mineração Rio do Norte, p. 96.

26 ÅKERØ et al. Norge i Brasil, p. 42. Imigrantes também se estabeleceram na cidade satélite, a maioria oriunda do Nordeste. Ver FLANAGAN, William e WHITEMAN, Gail. Ethics Codes and MNCs as Minority Shareholders. The Case of a Bauxite Mine in Brazil. In: CRAGG, Wesley (Ed.). Ethics Codes, Corporations, and the Challenges of Globalization. Cheltenham: Edward Edgar Publishers, 2005, p. 218. PINTO. Amazônia: o século perdido.

27 DE SIQUEIRA. Mineração Rio do Norte, p. 72.

28 GIRNDT. Bergbau in Brasilien.

29 PINTO. Amazônia: O século perdido. 
baixo e a rotatividade grande. No outono de 1978, estourou um motim quando uma multidão de 2.000 trabalhadores começou a jogar pedras nos seguranças que não haviam deixado um trabalhador doente ir para frente da fila da comida e pôs fogo nos alojamentos. A empresa privada de segurança interveio e acabou com o motim, colocando 30 amotinados na prisão local..$^{30}$ Desde essa época, as condições para a organização dos trabalhadores mudaram radicalmente em função do crescimento de mobilizações em todo o país no período da transição democrática. No início, os trabalhadores de Porto Trombetas se juntaram à organização 'guardachuva' do Sindicato dos Trabalhadores das Indústrias Extrativas do Pará e Amapá. A distância da sede do sindicato no Amapá contribuiu para um sentimento de marginalização que se resolveu com a criação de um sindicato local autônomo, o Sindicato dos Trabalhadores das Indústrias Extrativas de Metais Não Ferrosos de Oriximiná (correspondente à sigla STIEMNFO), em 1989. ${ }^{31}$

Cerca de 6.200 pessoas viviam em Porto Trombetas na virada para o século XXI.32 A cidade-empresa incluía a vila residencial para os empregados, o terminal de bauxita e o porto de águas profundas com atracadouros e guindastes de carregamento. Desde a década de 1980, quando todas as instalações tecnológicas já estavam prontas, a infraestrutura social e cultural de Porto Trombetas foi desenvolvida significativamente. Isto era necessário para evitar uma alta rotatividade entre os trabalhadores especializados..$^{33}$ A comunidade contava com uma escola que oferecia educação até o nível secundário e tinha capacidade para mil estudantes; um hospital com serviços laboratoriais completos; clubes; um cinema e um teatro; um centro comercial; e um aeroporto. ${ }^{34}$

\section{Consequências sociais e ambientais}

O início das atividades mineradoras e a construção da cidade-empresa criaram uma nova realidade social em Porto Trombetas. As experiências dos trabalhadores variaram grandemente de acordo com a categoria ocupacional, mas também com a etnia. De forma análoga a cidades-empresa em enclaves ou em situações coloniais, em Porto Trombetas havia uma nítida divisão entre os recém-chegados - uma população essencialmente branca de trabalhadores especializados e sob contrato e os trabalhadores não qualificados das comunidades quilombolas. ${ }^{35}$ De acordo com Candance Slater, esta diferença étnica era reforçada por atitudes racistas. ${ }^{36}$ Para além disso, as próprias comunidades quilombolas eram divididas em dois grupos diferentes, dependendo de seus membros serem ou não empregados na mina. Assim, para as comunidades locais, a atividade mineira aumentou a disparidade econômica e contribuiu para um desequilíbrio social crescente.

Trabalhadores regulares da mina e suas famílias, cuja maior parte era especializada e essencialmente branca, beneficiavam-se do que a empresa

30 ÅKER $\varnothing$ et al. Norge i Brasil, p. 38-50; GIRNDT. Bergbau in Brasilien.

31 Para maiores informações, ver o website do sindicato http://www.stiemnfo.org.br.

32 http://www.mrn.com.br/english/quem_somos/portotrombetas.html.

33 DE SIQUEIRA. Mineração Rio do Norte.

34 http://www.mrn.com.br/english/quem_somos/portotrombetas.html; DE Siqueira. Mineração Rio do Norte, p. 69.

35 Para uma comparação, ver as análises de Fushun, Catumbela e East Kalimantan em BORGES e TORRES. Company Towns.

36 SLATER. Entangled Edens, p. 164. Em Årdal, por outro lado, houve apenas uma divisão étnica marginal do trabalho, limitada ao caso dos trabalhadores imigrantes suecos na fase inicial da construção. Em função disso, a força de trabalho tem sido etnicamente mais homogênea. 
chamava comunidade de bem-estar. Fotografias do centro residencial tiradas por visitantes mostram pessoas bem vestidas em frente a bangalôs, em pequenos jardins com mobiliário adequado e estátuas de duendes, carros modernos, picapes e bicicletas de crianças. Outras fotografias mostram a piscina pública descoberta da vila e um porto para pequenas embarcações. ${ }^{37}$ Nos relatos de jornais, os trabalhadores da cidade-empresa enfatizam a ausência de problemas comuns às principais cidades brasileiras, como criminalidade elevada e drogas. ${ }^{38}$ Por outro lado, era difícil lidar com o isolamento, e uma viagem de avião para Belém, a capital do estado do Pará, equivalia a um salário mensal. Um dos benefícios adicionais que a empresa oferecia a estes trabalhadores eram as férias de seis semanas por ano. No polo oposto aos trabalhadores, estavam os membros das comunidades quilombolas, que representavam a classe inferior. Para os trabalhadores locais, na mina só havia trabalho não qualificado e mal pago. Os que trabalhavam em tempo integral recebiam menos de $60 \%$ do salário de um trabalhador branco qualificado. As oportunidades para as mulheres locais estavam limitadas ao trabalho em tempo parcial e doméstico. ${ }^{39}$

A mineração e a criação da cidade-empresa também trouxeram outras consequências socioeconômicas para as comunidades quilombolas. Por causa da introdução de um mercado monetário para os produtos locais, houve um declínio na economia tradicional de subsistência, na mesma medida em que as relações econômicas se tornavam crescentemente comerciais. Todavia, era difícil para os membros das comunidades quilombolas locais ter acesso ao mercado na mina. Estavam proibidos de vender para a população da cidade-empresa porque, de acordo com os funcionários da mina, não podiam oferecer garantia de produção. Desta forma, a maioria dos comerciantes no mercado local não fazia parte da comunidade quilombola local, antes vinha de Oriximiná ou, até, de lugares mais remotos, como Santarém.

Afora isso, as áreas tradicionalmente usadas para atividade econômica foram bastante reduzidas quando as autoridades nacionais decretaram uma zona extensa de reserva biológica (1979) e floresta nacional (1989) nos arredores da mina. Ambas foram estabelecidas como contrapartida às atividades de mineração na área. Apesar de meritórias do ponto de vista ambiental, estas mudanças no uso da terra tiveram um impacto negativo sobre a comunidade local. Para as comunidades quilombolas, as mudanças implicavam que matérias-primas, tais como madeira para construção, aquecimento e cozinha, passassem a ter que ser compradas. Além disso, não podiam mais usar estas duas áreas protegidas para a colheita de castanha-do-pará e para a pesca comercial. ${ }^{40}$

Os custos ambientais da produção industrial em Porto Trombetas eram

37 Este material está disponível na busca de imagens do Google e em www.flickr.com. http://www.youtube. com/watch?v=FU4vgaB1ofE. Vide também Girndt. Bergbau in Brasilien.

38 "Não temos aqui os problemas existentes na maioria das cidades", Gazeta Mercantil, São Paulo, 28 de março de 2002 (www.amazonia.org.br/noticias/print.cfm?id=8879); Girndt. Bergbau in Brasilien, p. 2.

39 FLANAGAN e WHITEMAN. Ethics Codes and MNCs as Minority Shareholders, p. 228-30.

40 DIEGUES, Antonio Carlos. Social Movements and the Remaking of the Commons in the Brazilian Amazon. In: GOLDMAN, Michael (org.). Privatizing Nature: Political Struggles for the Global Commons. Londres: Pluto Press, 1998, p. 70-1. ACEVEDO, Rosa e CASTRO, Edna. Negros do Trombetás: guardiães de matas e rios. Belém: UFPA/NAEA, 1993, p. 207. WANDERLEY, Luiz J. O grande projeto minerador e seus impactos territoriais de localização: o caso da MRN em Oriximiná-PA. Grupo de Pesquisa Mineração e Desenvolvimento Sustentável, 2004 (http://www3.ufpa.br/projetomineracao/docs/estrut/artigo_Luiz_(CNPq).pdf). WANDERLEY, Luiz J. Conflitos e impactos ambientais na exploração dos recursos minerais na Amazônia, 2008 (http://publique.rdc.puc-rio.br/geopuc/media/Wanderley_geopuc03.pdf). 
significativos. ${ }^{41}$ Houve três tipos principais de consequências ambientais decorrentes da atividade de mineração. Primeiro, grandes áreas foram desflorestadas, o que resultou, como comentado por alguns observadores, em "solo vermelho até onde a vista pode atingir" no meio da Amazônia. ${ }^{42}$ Como Glenn Switkes explicitou, "mesmo quando o solo de cobertura é restaurado após as atividades de mineração, o solo perde a capacidade de reter água, tornandose inadequado para plantações anuais". ${ }^{43} \mathrm{Em}$ segundo lugar, o minério era lavado com água corrente e os resíduos deste processo eram jogados no reservatório local de água doce, o Lago Batata. Na medida em que a lavagem do minério não empregava substâncias tóxicas, o principal problema era a significativa sedimentação e extrema degradação do lago. Nos primeiros cinco anos de produção, 10 milhões de toneladas de lama foram jogados no lago, reduzindo sua superfície em 15\% e levando ao desaparecimento e morte da vegetação e animais locais. ${ }^{44}$

Os dejetos da bauxita (resíduos de lavagem e pó de bauxita no ar) também poluíram outros reservatórios de água doce como os da área de Água Fria, assim como córregos e até mesmo o rio Trombetas. Para além disso, os poços de água doce perfurados pela mineradora mostraram-se fontes inadequadas de água potável, exigindo das comunidades quilombolas que buscassem água para beber e para lavagem em fontes distantes. Em terceiro lugar, navios vieram com carregamentos de água salgada como lastro, que era então descarregado no rio antes de carregar a bauxita. Esta prática teve um forte impacto na ecologia local de água doce e nas atividades piscatórias, em termos de espécies invasoras de flora e fauna. Houve também outras consequências da atividade de mineração, tais como sistema ineficiente de tratamento de esgotos, com descarregamento diretamente no rio; poluição sonora que afastou animais e perturbou a vida das comunidades; outras formas de poluição do ar e da água que conduziram a uma escassez de animais selvagens e de peixes; e, em especial no verão, pesca indiscriminada pelos empregados da mina com frequência usando armas de ar comprimido.

A mineração também teve consequências na saúde da população das comunidades quilombolas, sobretudo por seus efeitos poluidores nos mananciais de água causando vermes e diarreia. Os sistemas de purificação colocados pela mineradora funcionavam mal e eram retirados, mas nunca substituídos. Estes problemas vinham associados à falta de assistência médica para os que não faziam parte da comunidade da mineradora. As mulheres quilombolas estavam particularmente em desvantagem, sobretudo as solteiras que enfrentavam dificuldades para registrar seus filhos no centro de saúde. ${ }^{45}$

41 FLANAGAN e WHITEMAN. Ethics Codes and MNCs as Minority Shareholders; PINTO. Amazônia: O século perdido, p. 89. SLATER. Entangled Edens, 162-3, 270; GIRNDT, Cornelia. 'Bei unds bleibt der Dreck': Aluminium von Amazonas. Amazonien: Stadt, Land, Fluss: Das grösste zusammendhängende Regenwaldgebiet der Erde zwischen Schutz und Nutzung. Berlin: FDCL-Verlag, 2009, p. 86-9. Ver também os artigos do jornalista norueguês Roar NERDAL sobre os investimentos da Hydro na Alunorte e os problemas ambientais para os pesqueiros locais em Barcarena, in Dagens Nceringsliv, 24 de abril de 2008, 25 de abril de 2008 e 30 de abril de 2008.

42 Acessar: http://www.hydro.com/no/Pressesenter/Nyheter/Arkiv/2002/Mai/15888. Ver também DE SIQUEIRA. Mineração Rio do Norte, p. 153-5. SPONSEL, Leslie. The Environmental History of the Amazon. Natural and Human Disturbances, and the Ecological Transition. In: STEEN, Harold e TUCKER, Richard (orgs.). Changing Tropical Forests. Historical Perspectives on Today's Challenges in Central and South America. Durham, N.C: The Forest History Society Group, 1992, p. 233-51.

43 SWITKES, Glenn. Foiling the Aluminium Industry: A Toolkit for Communities, Activists, Consumers and Workers. Berkeley: Cal. International Rivers Network, 2005, p. 5.

44 PINTO. Amazônia: o século perdido, p. 89, 96-7; Switkes. Foiling the Aluminium Industry, p. 5. Ver também DE SIQUEIRA. Mineração Rio do Norte, p. 155-9.

45 FLANAGAN e WHITEMAN. Ethics Codes and MNCs as Minority Shareholders, p. 228-30. 
As mudanças demográficas também tiveram consequências na saúde local, particularmente em função do crescimento populacional de homens sem laços sociais - mais especificamente, aumento no consumo de bebidas alcoólicas e na prostituição. As comunidades quilombolas reclamaram dos efeitos disto entre seus jovens, incluindo-se relatos de práticas de prostituição entre garotas de até 13 anos de idade. ${ }^{46} \mathrm{Em}$ consequência da atividade laboral de desflorestamento, os trabalhadores que viviam nas comunidades ribeirinhas estiveram expostos a doenças parasitárias como leishmaniose, malária e febre amarela. Em relação às doenças infectocontagiosas houve incidência e disseminação de tuberculose e hanseníase, provenientes dos trabalhadores que migraram e viviam no entorno de Porto Trombetas. ${ }^{47}$

Todavia, nem todas as consequências do contato com o mundo exterior trazido pela mineradora e pela construção da cidade-empresa da MNR foram negativas para as comunidades quilombolas locais. ${ }^{48} \mathrm{Com}$ o fim da ditadura militar em 1985 e a adoção de uma nova Constituição em 1988, as populações locais brasileiras ganharam acesso aos mecanismos de resposta às violações dos seus direitos tradicionais e às ameaças a seus sistemas econômicos e de valores. O Movimento Negro, que organizava os afro-brasileiros e era apoiado por vários intelectuais, foi bem sucedido na tentativa de incluir na nova Constituição Federal mecanismos de garantia de direitos culturais e territoriais. ${ }^{49} \mathrm{O}$ novo ambiente político que acompanhou o retorno à ordem democrática na década de 1980 levou à criação de organizações de base. Em 1989, os habitantes de 21 comunidades quilombolas na grande área do Trombetas fundaram a Associação dos Remanescentes dos Quilombos do Município de Oriximiná (ARQMO). Esta organização conseguiu ultrapassar os temas locais e colaborou com associações mais amplas, de âmbito regional, nacional e internacional, em temas ambientais e ligados à questão indígena. Em função da conexão nacional e internacional, as comunidades quilombolas puderam dar início a ações legais de definição de limites para aquisição de terra por corporações multinacionais..$^{\circ} \mathrm{A}$ comunidade quilombola de Boa Vista, perto de Porto Trombetas, foi a primeira a ganhar a outorga de direitos fundiários ao abrigo da Constituição de 1988; outras dezesseis comunidades da área posteriormente conseguiram sucessos análogos. ${ }^{51}$

Para além das mudanças políticas e dos movimentos sociais em nível nacional, o aumento no monitoramento internacional no tocante aos direitos ambientais e de minorias também teve um efeito positivo na vida das comunidades quilombolas e no meio ambiente local..$^{52} \mathrm{~A} M R N$ introduziu novas práticas para minorar os danos ambientais. Como compensação pelo desflorestamento de vastas áreas de floresta amazônica, a MRN empregou um ecologista para trabalhar com reflorestamento e criou vários viveiros de árvores nativas para replantio..$^{53} \mathrm{O}$ processo de reabilitação implicava na remoção cuidadosa da fina camada de solo superficial do local de

46 Idem.

47 FERRAZ, Thais de Araújo. The Impacts and Implications of Industrial Development on Riverine Communities on the Banks of Trombetas River in Pará, Brazil. Oslo: Oslo University College, 2011.

48 DAVIS. Victims of the Miracle.

49 Price. Scrapping Maroon History, p. $237 f$.

50 SLATER. Entangled Edens, p. 163.

51 DE SIQUEIRA. Mineração Rio do Norte, p. 33.

52 DIEGUES. Social Movements and the Remaking of the Commons, p. 56.

53 PRANCE, Ghillean. The Amazon: Paradise Lost? In: KAUFMANN Les e MALLORY Kenneth (orgs.). The Last Extinction. Boston: MIT Press, 1993, p. 69-114. PARROTTA John e KNOWLES, Oliver. Restoring Tropical Forests on Lands Mined for Bauxite. Examples from the Brazilian Amazon. Ecological Engineering, vol. 17, n²-3, p. 219-39, 2001. 
mineração, preservada enquanto se minerava a área e recolocada após a extração do minério. A MRN também deu início a um programa de monitoramento ambiental. ${ }^{54}$ Os assentamentos quilombolas ganharam pequenas máquinas de purificação para tratar a água e a empresa deu início a uma limpeza parcial do Lago Batata.

Essa virada em direção às práticas ambientalmente conscientes começara antes mesmo do retorno do Brasil à democracia, quando, em dezembro de 1982, a empresa instalou filtros para remoção de poeiras ao custo de 15 milhões de dólares. ${ }^{55}$ Mas as mudanças políticas de meados da década de 1980 abriram caminho para transformações mais significativas. Como um todo, após o retorno do Brasil ao estado democrático em 1985, desenvolvimentos locais e internacionais implicaram em melhoras consideráveis nas condições de trabalho e de vida em Porto Trombetas - em particular, uma colaboração crescente das comunidades quilombolas com organizações ambientais e de direitos de minorias nacionais e internacionais; a implementação de monitoramento internacional das práticas corporativas ambientais e de responsabilidade social; e a pressão das organizações sindicais. ${ }^{56}$

\section{Årdal: a criação de uma cidade de uma única indústria, antes do alumínio}

Årdal está localizada na costa oeste do sul da Noruega, a cerca de $300 \mathrm{~km}$ a noroeste de Oslo e a $250 \mathrm{~km}$ a nordeste de Bergen, na parte mais interna de Sognefjord, o maior fiorde da Noruega. Tradicionalmente, o município de Årdal consistia em dois centros: Årdalstangen, situado na beira do fiorde e com um porto; e Øvre Årdal (Alta Årdal), onde uma usina de fundição foi construída na década de 1940. Ao longo da maior parte de sua história, os habitantes locais viviam como coletores, pastores, agricultores e pescadores. Em contraste com as comunidades nas margens do rio Trombetas, a comunidade de Årdal não estava isolada, mas conectada a uma economia regional mais ampla, a partir do comércio de peixe e de produtos agrícolas. Desde 1814, funcionários do governo, habitantes de cidades e agricultores da comunidade tinham direito a votar nas eleições nacionais e desde 1838 a comunidade gozava de autogoverno. Este cenário democrático ampliouse e modificou-se e, fora os anos de ocupação alemã (1940-45), nunca deixou de existir.

Årdal desenvolveu laços com a economia internacional desde quando a mina de cobre Gottes Gabe (Presente de Deus) se estabeleceu no início do século XVIII. A mina fracassou e foi fechada pouco depois de criada, e novamente fechada após ter sido reaberta em meados do século XVIII. Não obstante, Årdal teve uma experiência precoce como parte de uma rede econômica transnacional, com conexões financeiras e de trabalho com Copenhagen, onde o Rei conduzia seus negócios; com Amsterdam, à época o centro do comércio de cobre na Europa; e com a Alemanha, onde eram recrutados os trabalhadores especializados para a

54 FLANAGAN e WHITEMAN. Ethics Codes and MNCs as Minority Shareholders, p. 228-30.

55 PINTO. Amazônia: O século perdido, p. 99.

56 VIDAL LUNA, Francisco e KLEIN, Herbert. Brazil since 1980. Cambridge: Cambridge University Press, 2006. GWYNNE, Robert e Kay, Cristóbal (orgs.). Latin America Transformed: Globalization and Modernity, 2nd ed. Londres: Nova York: Edward Arnold, Oxford University Press, 2004. STEEN e TUCKER (orgs.). Changing Tropical Forests. 
mina. ${ }^{57}$ Nos 150 anos seguintes, Årdal desligou-se das redes internacionais e sua economia baseou-se sobretudo em atividades tradicionais como a agricultura e a pesca. O único centro urbano significativo era Tangen, no fiorde, onde algumas casas de madeira, lojas, o correio e o posto de polícia se alinhavam ao longo de uma única rua. ${ }^{8}$

\section{Desenvolvimento industrial e a transformação de Årdal}

O processo de incorporação na cadeia produtiva global começou mais cedo e progrediu mais lentamente em Årdal do que em Porto Trombetas. Por vezes o processo sofreu uma pausa e até cessava; em outros momentos, particularmente durante os anos da ocupação alemã, o ritmo do desenvolvimento industrial acelerava-se e tornou-se comparável ao rápido desenvolvimento de Porto Trombetas. Após a passageira tentativa de industrialização no século XVIII, o processo de transformação industrial de Årdal deu-se, sobretudo, na primeira metade do século XX. A produção de alumínio foi antecedida por uma fase inicial de desenvolvimento da produção hidroelétrica.

A transformação plena de Årdal em centro de produção hidroelétrica levou quarenta anos, de 1907 a 1947. Começou quando os advogados Jens P. Heyerdahl e Ch. C. Platou de Christiania pediram autorização, em nome de um empreendimento conjunto alemão-norueguês, para construir um curso de água, afirmando que o projeto traria ao "pequeno e pobre município de Årdal” benefícos sob a forma de impostos, melhores linhas de comunicação e mercados para os produtos agrícolas. ${ }^{59}$ A câmara de vereadores local foi a favor da solicitação, bem como os 323 moradores que apuseram seus nomes a uma "Declaração dos Habitantes de Årdal”. ${ }^{60}$

Um fator crucial para o apoio da comunidade era a salvaguarda da propriedade dos vastos recursos hídricos necessários à produção de energia hidroelétrica. Em contraste com Porto Trombetas, os moradores locais mantiveram o controle final dos recursos naturais. A lei reguladora da distribuição de concessões na Noruega garantia desde o início do processo de desenvolvimento industrial que os recursos naturais de Årdal fossem meramente objeto de aluguel - não estavam à venda - a empresas internacionais. Há um consenso geral entre os historiadores noruegueses de que as leis reguladoras da propriedade da produção hidroelétrica (Konsesjonslovene) asseguraram o controle norueguês da produção, assim tendo um papel vital na proteção da economia do país contra a dependência de interesses estrangeiros. ${ }^{61} \mathrm{O}$ Parlamento norueguês aprovou as condições para a construção da usina hidroelétrica em agosto de 1908 e concedeu a licença por decreto real à empresa de capital aberto Tyinfald um mês depois.

Os trabalhos para erigir a usina começaram em fevereiro de $1910 \mathrm{com}$ a construção das estradas necessárias e a infraestrutura portuária. Foram

57 JOHANNESSEN, Finn Erhard. Mykje skrik og lite gull. In: AMDAM et al (org.). Årdal, p. 24-37.

58 LÆGREID, Erling. Eg burde ha hata Verket. In: AMDAM et al (org.). Årdal, p. 274. FOSSO, Eli Janette. Industriens barn. In: AMDAM et al (org.). Årdal, p. 205.

59 RINDE, Harald. Den lange ventetida. In: AMDAM et al (org.). Årdal, p. 63. Christiania era o nome da capital norueguesa até 1923, quando mudou para Oslo.

60 Idem.

61 ST. MELD, №. 67 (1974-1975), Norsk industris utvikling i fremtid. Oslo: Industridepartementet. 4.4.1975, p. 106. 
suspensos temporariamente no outono de 1911, quando os proprietários alemães abandonaram o projeto por causa de discordâncias no tocante à tecnologia de produção a ser utilizada na usina. Os acionistas alemães venderam suas ações para a companhia de fertilizantes Hydro, de propriedade norueguesa. ${ }^{62} \mathrm{~A}$ Hydro não queria completar a usina como fora planejada e uma vez após outra aportava razões para adiar sua conclusão. Antes da Segunda Guerra Mundial, os planos em relação ao que era para ser produzido em Årdal mudavam com frequência. O número de empregados também variava muito. A força de trabalho inicial consistia de cerca de 200 trabalhadores. No verão de 1914, toda a força de trabalho foi demitida sem aviso prévio por causa das dificuldades em financiar a usina. Contudo, a Hydro tinha que manter um número mínimo de empregados por causa das condições estabelecidas pela licença. No período entre 1921 e 1932, de 80 a 145 homens trabalhavam no canteiro de obras. ${ }^{63}$ Em contraste com Porto Trombetas, a maioria dos trabalhadores iniciais foi recrutada localmente, das pequenas propriedades agrícolas próximas, casas rurais e vilarejos da vizinhança. Também havia alguns poucos trabalhadores suecos na usina nos primeiros anos, que davam treinamento aos trabalhadores locais. Contudo, os trabalhadores estrangeiros foram os primeiros a ser demitidos quando a Hydro precisou reduzir custos. ${ }^{64}$

A transformação gradual de Årdal numa comunidade industrial mudou radicalmente com a Segunda Guerra Mundial, quando a ocupação alemã levou a um período de industrialização que se assemelha ao ritmo rápido de desenvolvimento de Porto Trombetas. A Alemanha precisava desesperadamente de alumínio, em especial para a produção de aviões. De acordo com os planos alemães, a bauxita seria provida pela Ucrânia e a produção sextuplicaria até 1944. Na primavera de 1941, as condições da ocupação forçaram a Hydro a vender a empresa à Nordage, uma companhia de propriedade alemã. De 1940 a 1945, a construção acelerouse sob o comando das forças alemãs de ocupação, o que resultou na conclusão da estrada conectando os dois centros e na construção da usina hidroelétrica, bem como de parte da zona de oxidação (que nunca chegou a ser terminada) e da zona de fundição. Segundo Erling Lægreid, que testemunhou estas mudanças quando criança, os prados do estreito vale onde se encontra Årdal ficaram juncados por construções fabris inacabadas, pilhas de dejetos, estruturas de ferro, trilhos e dormentes de trem, pilhas de placas de compensado para a ossatura das construções e grandes bolas de ferro. Havia sujeira, pó e ruído de maquinário. O cais foi ampliado com docas ao longo da costa, onde barcas, rebocadores, cargueiros e ferryboats de passageiros ficavam ancorados nas proximidades. ${ }^{65}$

O aumento nas atividades atraiu mais trabalhadores para Årdal, e em pouco tempo a área ficou superpovoada. Em 1942, quando as atividades estavam no seu auge, quase 6.000 trabalhadores viviam em Årdal, que vinte anos antes havia apenas 1.600 habitantes. A maioria era de noruegueses, com alguns alemães e dinamarqueses. A maior parte dos trabalhadores imigrantes era abrigada em barracões construídos rapidamente e com más condições sanitárias. As condições de vida e trabalho levavam a uma grande rotatividade. Permanentemente, $20 \%$ dos trabalhadores estavam doentes, de férias ou de licença por outros motivos. Em 1942, quando os alemães precisavam de todos os recursos disponíveis na frente oriental, a força de trabalho foi desmobilizada e a construção das instalações

62 RINDE. Den lange ventetida, p. 64.

63 Idem, p. 67 ff.

64 Idem, p. 68 ff.

65 LÆGREID. Eg burde ha hata Verket, p. 274. 
técnicas em Årdal interrompida. Em junho de 1943, o processo foi reiniciado, desta feita com uso substancial de trabalho forçado. Entre março de 1943 e setembro de 1944, pelo menos 1.200 trabalhadores soviéticos (tanto civis como prisioneiros de guerra) foram levados para Årdal, além de cerca de 650 franceses e 1.200 voluntários noruegueses.

De início, as autoridades alemãs pretendiam classificar os trabalhadores forçados de acordo com uma hierarquia étnica, o que limitava os soviéticos ao trabalho subordinado. Todavia, uma carência de trabalhadores especializados minou tal plano e os trabalhadores civis soviéticos foram promovidos a posições especializadas e alguns até se tornaram capatazes. Em setembro de 1944, quando os alemães interromperam o trabalho em Årdal, os trabalhadores soviéticos foram mandados para pequenos campos de trabalho no leste e no sul da Noruega, ao passo que a maior parte dos trabalhadores civis franceses foi transportada de volta para casa. As condições de trabalho e de vida para os trabalhadores forçados eram duras. Um grupamento de guardas alemães, chamado Werkschutz (proteção do trabalho), impedia que os prisioneiros cometessem atos de sabotagem e de resistência. ${ }^{66}$ Quando ocorreu a capitulação alemã, os trabalhadores forçados e voluntários tinham praticamente completado a usina hidroelétrica e montado três dos cinco geradores de energia elétrica. Na usina de fundição todos os fornos de uma área da fábrica estavam prontos e concluida a construção da segunda área. ${ }^{67}$

Depois da Segunda Guerra Mundial a produção de energia hidroelétrica tornou-se a base da industrialização em Årdal, com o pleno desenvolvimento da produção de alumínio. A decisão de estabelecer uma indústria que exigia enorme quantidade de energia elétrica não deixou, todavia, de ser contestada pelos habitantes locais. Era preciso uma política nacional para subsidiar o preço da eletricidade de modo a tornar rentável a operação da usina de fundição. O projeto contava com total apoio político do Partido Trabalhista Norueguês, cujos líderes defendiam o desenvolvimento de grandes projetos industriais, especialmente os voltados para mercados internacionais. ${ }^{68} \mathrm{O}$ alumínio tornou-se a atividade dominante de Årdal. Apesar de esforços do município e nacionais no sentido de diversificar a economia local, nenhuma alternativa de peso em termos de emprego cresceu à sombra da produção de alumínio.

\section{Consequências sociais e ambientais}

A mudança completa para produção de alumínio após a Segunda Guerra Mundial implicou em mudanças demográficas significativas. A imigração regional de trabalhadores masculinos dos vilarejos próximos aumentou consideravelmente a população de Årdal. Diferentemente do crescimento artificial da população no período da ocupação alemã, este crescimento acompanhava as novas oportunidades de trabalho e não resultava de nenhuma coerção. Em 1946, havia

66 SOLEIM, Marianne Neerland. Sovjetiske krigsfanger i Norge 1941-1945: Antall, organisering og repatriering. Oslo: Scandinavian Academic Press/Spartacus Forlag, 2009, p. 156. STEFFENAK, Einar Kr. Russerfangene: Sovjetiske krigsfanger i Norge og deres skjebne. Oslo: Humanist Forlag, 2008, p. 93-4. STOKKE, Michael. Sovjetiske og franske sivile tvangsabeidere i Norge 1943-1945: En sammenligning av arbeids- og leveforhold. Bergen: Universitetet i Bergen. Institutt for arkeologi, historie, kultur- og religionsvitenskap, 2008, p. 32. RINDE. Den lange ventetida, p. 72-7.

67 RINDE. Den lange ventetida, p. 77 ff

68 LANGE, Even. Samling om felles mål. Aschehougs Norgeshisstorie. vol. 11, Oslo 1998, p. 156-8, 169-70; Bergh, Trond. Storhetstid: 1945-1965. Oslo. Tiden, 1987, p. 165-6 e 197. 
500 trabalhadores empregados na usina. Quatro anos mais tarde, o número de trabalhadores chegara a 1.400, número que era superior ao total da população de Årdal em meados da década de 1930. Destes, apenas 300 trabalhadores tinham nascido em Årdal. A população local cresceu $72 \%$ entre 1946 e 1950 e outros 63\% na década seguinte. A população continuou a crescer num ritmo menos acelerado até a década de 1970 e começou a declinar na década de $1980 .{ }^{69}$

O afluxo maciço de pessoas colocou problemas de moradia. No pós-1945, os barracões construídos pelas tropas alemãs eram plenamente utilizados para albergar os novos trabalhadores. Os trabalhadores de barracões - todos homens e não especializados - viviam isolados do resto da comunidade de Årdal. Espaços habitacionais pequenos eram partilhados por quatro ou cinco trabalhadores. Más condições de vida contribuíram para uma rotatividade já em si elevada. A maioria dos trabalhadores deixava a fábrica antes de completar seis meses de emprego. ${ }^{70}$ Como em outras cidades-empresa, uma das estratégias desenvolvidas pela companhia para reduzir a rotatividade foi melhorar as condições de moradia dos trabalhadores e a infraestrutura da cidade. Até 1959, a empresa construíra mais de 300 casas ou apartamentos, o que correspondia a 30\% do total de moradias em Årdal. A fábrica cobria dois terços dos custos da construção. ${ }^{11}$ Trabalhadores casados podiam juntar-se a suas famílias. No início da década de 1960, a empresa criou duas comunidades residenciais modernas na estreita faixa de terra entre o Sognefjord e Jotunheimen, que dispunham de facilidades de lazer e serviços. ${ }^{72}$

Não havia, contudo, nenhum macro plano de desenvolvimento urbano, típico das cidades-empresa modelo, como no caso de Hellerau, na Alemanha. ${ }^{73}$ Nos termos de Erling Lægreid, a cidade assemelhava-se a um "maxilar deformado". ${ }^{74} \mathrm{Em}$ contraste com outras comunidades norueguesas de um único empreendimento, como Sauda ou Rjukan, e com outras cidades-empresa, em Årdal não havia uma rígida divisão espacial de classes. A não ser pelos altos escalões, todos os trabalhadores da fábrica de alumínio viviam nas mesmas áreas, participavam dos mesmos clubes e associações de moradores e circulavam socialmente nos mesmos lugares..$^{75}$ Além disso, não havia diferenças significativas entre os trabalhadores na usina e na comunidade como um todo. O enquadramento legal e socioeconômico do estado de bem estar social norueguês impedia grandes disparidades de renda e garantia um nível relativamente elevado de saúde pública. Durante a segunda metade do século XX, os trabalhadores noruegueses em Årdal desfrutavam de um elevado nível de vida e estavam protegidos por generosos seguros desemprego, aposentadorias e serviços de saúde. ${ }^{76}$

A fundição criou novos desafios ambientais e à saúde dos trabalhadores mobilizaram os moradores e foram objeto de preocupação nacional. A usina de Årdal liberava dióxido de enxofre e outros gases que provocavam o efeito estufa, mas o maior problema era a poluição decorrente da liberação de grande quantidade de fluoretos. Estes produtos químicos estavam contidos na fumaça solta pelos banhos de fundição nas fornalhas da usina. Na medida em que os

69 BUKVE, Oddbjørn. I skuggen av Verket. In: Amdam et al (org.). Årdal, p. 166-70.

70 FOSSO. Industriens barn, p. 206-11.

71 BUKVE. I skuggen av Verket, p. 166-70.

72 GJESTLAND, Dag. Gjensyn med Årdal. In: Amdam et al (org.). Årdal, p. 186 e 197.

73 Ver VAN ZEE, Marynel Ryan. Form and reform. The garden city of Hallerau-bei-Dresden, Germany, between Company Town and Model Town. In BORGES e TORRES. Company Towns, p. 41-67.

74 LÆGREID. Eg burde ha hata Verket, p. 275-80.

75 KJELDSTADLI. Å komme, å bli, å bygge, p. 62 e 66.

76 BERGH. Storhetstid. Lange. Samling om felles mål. 
fornos não eram cobertos, a fumaça espalhava-se pelo estreito vale ladeado por montanhas de mais de 2.400 metros de altura, as quais, junto com as condições atmosféricas dominantes, não permitiam a ventilação das massas de ar. Em 1949, depois de a fábrica haver funcionado por 18 meses, os moradores começaram a registrar os efeitos da poluição. Isto ficou primeiro evidente nas áreas de pecuária, com níveis de flúor cinquenta vezes acima do normal registrados nos ossos e na urina do gado. Como resultado de ações legais empreendidas por agricultores do lugar, em 1952 os tribunais exigiram que a fábrica de Årdal pagasse indenizações que chegavam a 500.000 coroas norueguesas, afora os custos legais. ${ }^{77}$ Não apenas agricultores, mas também trabalhadores da usina e suas famílias - e, em particular, donas de casa - sentiram as consequências da poluição da fumaça. Asma, como resultado das atividades da fábrica, é um fenômeno bem conhecido e uma doença corrente entre trabalhadores da indústria do alumínio em geral.

O Instituto Norueguês de Promoção da Saúde na Indústria declarou, em 1960, que a poluição nas fábricas era a causa da asma que afligia os trabalhadores. Além disso, o Instituto sustentou que os trabalhadores dessas fábricas tinham maior risco de desenvolver câncer. ${ }^{78}$ Apesar dessas evidências, a poluição aumentou com a expansão da usina. No início da década de 1960, as fábricas Årdal II e Årdal III entraram em produção. No inverno de 1962/63, a fuligem emitida pelos fornos começou a causar problemas. Condições atmosféricas fizeram com que a fuligem se assentasse sobre as áreas residenciais localizadas perto da usina. "Uma nuvem de fuligem desceu sobre tudo como um véu", publicou um jornal da região, e prosseguiu: "Poucos dias após uma queda de neve, toda a neve ficou negra. As crianças que brincam fora estão tão sujas quanto os trabalhadores que voltam para casa após seus turnos na fábrica". ${ }^{79} \mathrm{~A}$ fuligem poeirenta também sujou todas as roupas penduradas fora para secar, bem como as janelas e pisos das casas dos trabalhadores. O comércio local aumentou suas vendas de sabão e detergentes nesse inverno. Por causa dos efeitos da fuligem nas roupas e nas casas, não é de surpreender que o Clube de Mulheres do Partido Trabalhista de Alto Årdal tenha sido o primeiro a apontar o problema da poluição. "A opinião generalizada entre as donas de casa é que a fumaça e a fuligem ameaçadoras estão cada vez piores" constava de carta enviada à seção de Årdal do Partido Trabalhista. A posição da comunidade local, contudo, não era homogênea. Agricultores e trabalhadores industriais nem sempre partilhavam as mesmas ideias quanto às ações mais adequadas. Em vários momentos, o Partido Trabalhista ventilou queixas relativas aos problemas da poluição, mas defrontou-se com certa resistência local na medida em que a fumaça e a fuligem eram produzidas pela atividade industrial que punha comida na mesa da maior parte das famílias da comunidade. ${ }^{80}$

No final da década de 1960, movimentos ambientalistas e instituições locais e nacionais começaram a enfrentar a poluição industrial de maneira mais firme. Uma antiga floresta de abetos próxima de Årdal, localizada numa zona que deveria ser incluída no Parque Nacional de Jotunheimen, foi fortemente afetada pela poluição, um acontecimento que chamou a atenção pública. Autoridades da área agrícola foram a principal força por detrás do desenvolvimento de instituições de proteção ambiental - como, por exemplo, o Comitê Local de Årdal para Investigar Danos

77 BYRKJELAND, Martin. Kampen mot fluoren. In: Amdam et al (org.). Årdal, p. 110-32; Lange. Samling om felles mål, p. 201.

78 BYRKJELAND. Kampen mot fluoren, p. 114-8.

79 Idem, p. 118.

80 Idem, p. 118-20. 
Causados por Fumaça, criado em 1956; e o Conselho Central contra os Danos de Fumaça, criado em 1962. ${ }^{81}$ O Conselho monitorou os pedidos de licenciamento de todas as novas empresas que poluíam o meio ambiente. Além disso, estabeleceu exigências rígidas para reforma das fábricas existentes de modo a que a poluição fosse reduzida. As exigências do Conselho forçaram a usina de Årdal a reduzir a sua poluição, num período de dez anos de 80 para 40 quilos de fluoretos por hora.

Em 1976, foi criada a Autoridade Estatal Norueguesa para o Controle da Poluição (SFT), em substituição ao Conselho e assumindo suas funções. A Lei Norueguesa de Combate à Poluição muniu o SFT do poder de multar as fábricas poluidoras. Em meados da década de 1980, quando a usina de Årdal excedeu em $25 \%$ o total de poluentes que estava autorizada a liberar, o SFT ameaçou multar a fábrica em oito milhões de coroas norueguesas para cada quilo de fluoretos que excedesse os limites estabelecidos na licença que detinham. ${ }^{82}$ Como reação a estas medidas, o Conselho de Administração da usina decidiu fechar os fornos da fábrica. Em 1970, os fornos mais antigos foram fechados, o que levou a uma diminuição dramática na emissão de fluoretos. Além disso, instalações para limpeza e um remodelamento do processo resultaram em emissões ainda mais baixas. ${ }^{83}$ Este era o único procedimento viável já que era impossível diluir os componentes tóxicos.

Do mesmo modo que em Porto Trombetas, a produção de alumínio também gerou impactos negativos substanciais no ambiente natural em Årdal. Não obstante, o montante da poluição na região de Årdal acabou por ser reduzido em função das ações da população local, que protestou contra as consequências indesejáveis da produção industrial, e das ações das agências nacionais. A presença de mecanismos legais claros e a relativa autonomia dos habitantes da cidade Ihes permitiram apelar às - e ser ouvida pelas - autoridades nacionais. Apesar destas ações, medidas efetivas contra a degradação ambiental demoraram um bom tempo para serem efetivadas. Como discutido acima, em Porto Trombetas políticas de proteção ambiental foram implementadas quando as condições sociopolíticas mudaram após o fim da ditadura militar. Quando se compara com o caso brasileiro, é notável quão pouco peso a comunidade de Årdal teve em termos de políticas ambientais antes da década de 1970, apesar da existência de canais de participação. Demorou para que os políticos se comprometessem com temas ambientais que envolviam confronto com interesses industriais e fosse estabelecido um equilíbrio entre viabilidade econômica de comunidades locais e o bem comum. A poluição em Årdal tornou-se um assunto político que denunciava o conflito de interesses entre agricultura e indústria e também entre Estado e empresas.

\section{Conclusão}

A participação na cadeia produtiva da bauxita e alumínio modificou Porto Trombetas e Årdal. As companhias criaram comunidades residenciais para seus trabalhadores e em grande medida, ou completamente, dominaram as economias

81 O comitê executivo era composto por representantes da usina, das propriedades agrícolas locais, pelo veterinário distrital e por um consultor agrícola. Idem, p. 116.

82 Idem, p. 126.

83 Quando a usina foi comprada pela Hydro em 1986, a administração concordou em reduzir a poluição. Mais do que isso, a Hydro queria ir além das exigências mínimas da STF e voltou sua atenção para outras fontes de poluição, além da dos fluoretos. 
locais. Ambas as comunidades partilharam características gerais de cidadesempresa, mas houve também variantes significativas, resultantes de seu relativo isolamento, do grau de autonomia da cidade face ao principal empregador, bem como da influência das condições locais e de desenvolvimentos históricos, econômicos e políticos mais amplos em nível nacional. Um enclave mineiro isolado, Porto Trombetas se assemelhou mais a uma cidade-empresa clássica do que Årdal, que pode ser classificada de modo mais apropriado como comunidade de empresa única. Embora os destinos de ambas as comunidades estivessem ligados por sua participação na cadeia produtiva global. Porto Trombetas era muito mais dependente das multinacionais que criaram a cidade. Neste sentido, Årdal gozava de um nível mais elevado de autonomia em relação à empresa.

O papel do Estado foi consideravelmente diferente nos dois casos, o que teve um impacto significativo no ritmo e na extensão do desenvolvimento industrial e em suas consequências sociais e ambientais. No período de poucos anos na década de 1970, Porto Trombetas se estabeleceu como comunidade mineira praticamente do nada numa região de floresta densa. Em Årdal, a geração hidroelétrica e a usina de alumínio resultaram de um processo que durou décadas, do início do século XX até o fim da Segunda Guerra Mundial. Em ambos os casos, todavia, nos períodos de autoritarismo (a ocupação alemã da Noruega, de 1940 a 1945, e a ditadura militar brasileira), o ritmo da industrialização foi muito mais acelerado do que durante as épocas de democracia.

As consequências ambientais foram significativas em ambos os casos. Embora a população de Årdal tivesse a possibilidade de reivindicar uma redução das emissões poluentes da usina de alumínio, através dos canais políticos da democracia representativa, a luta por responsabilidade ambiental corporativa prolongou-se por várias décadas. A companhia de mineração em Porto Trombetas introduziu medidas de redução dos danos ambientais quase que logo em seguida ao período de construção (mas, sobretudo, após o fim do controle militar). Quanto a isto, Porto Trombetas pode ter tido certas vantagens por ter chegado mais tarde. Não obstante, a construção da cidade-empresa e a mineração na área de Porto Trombetas implicaram em consequências negativas duradouras sobre as comunidades quilombolas locais. Foi apenas após o retorno do Brasil a um regime democrático que estas comunidades começaram a exercer pressão sobre a empresa e o governo nacional pela melhoria das condições. A colaboração com ONGs nacionais e internacionais em torno de temas de proteção ambiental e direitos de minorias também contribuiu para estas melhorias.

Com seus destinos ligados aos desenvolvimentos de uma única mercadoria, quais seriam os efeitos da mudança nas condições globais na virada para o século XXI? Seriam estas cidades-empresa capazes de se adaptar e transformar se a produção mineira e industrial segue o capital para outras partes do mundo globalizado? Projeções sobre gastos e lucros futuros com frequência levam à realocação do capital em locais alternativos de produção. À medida que o capital se movimenta ao redor do planeta, industrialização e desindustrialização tornamse os dois lados da mesma moeda. ${ }^{84}$

A comunidade de Årdal precisou confrontar-se com esta situação quando a

84 ALTENA, Bert e VAN DER LINDEN, Marcel. Preface. In ALTENA, BERT e VAN DER LINDEN, Marcel (orgs.). De-industrialization: Social, Cultural, and Political Aspects. International Review of Social History. Supplement, vol. 10, $n^{\circ}$ 47, p. 2, 2002. Johnson, Christopher. Introduction: De-industrialization and Globalization. In: ALTENA e VAN DER LINDEN. De-industrialization, p. 25. COWIE, Jefferson. Capital Moves: RCA's Seventy-Year Quest for Cheap Labor. Ithaca, N.Y: Cornell University Press, 1999. 
multinacional de alumínio Hydro decidiu fechar a sala de cadinhos de Söderberg em junho de 2007 e passou a demitir mais de uma centena de empregados, sob alegação de insegurança quanto aos custos futuros da energia hidroelétrica na Noruega. ${ }^{85}$ Devido ao fato de a produção de alumínio ser altamente dependente de energia barata, a Hydro reduziu sua capacidade produtiva e começou a procurar alternativas. ${ }^{86} \mathrm{~A}$ desindustrialização de Årdal conduziu a, pelo menos, dois tipos diferentes de reindustrialização. Inicialmente, o fechamento da usina levou a inquietação e incerteza entre os moradores locais quanto ao futuro da comunidade. Ao mesmo tempo, o recém-eleito governo nacional constituído por uma coalizão do Partido Trabalhista Norueguês, a Esquerda Socialista e o Partido do Centro começaram um debate sobre a política industrial do Estado e o desenvolvimento industrial nos distritos e nas áreas rurais da Noruega. De maior significado para a força de trabalho local foi a movimentação do governo no sentido de disponibilizar recursos para um fundo de reajustamento (Innovasjon Norge) que conduziu ao estabelecimento de novas indústrias, de produção de portas e de painéis de energia solar, em Årdal. ${ }^{87}$ Além disso, a Câmara Municipal de Årdal tentou convencer a Hydro a investir localmente no desenvolvimento de novas tecnologias. ${ }^{88} \mathrm{Em}$ segundo lugar, houve industrialização em outras partes do mundo. Já antes do fechamento das áreas mais antigas da usina de alumínio em Årdal, a multinacional Hydro desenvolvera projetos de estabelecer usinas de produção de alumínio em outros países de forma a compensar a queda na produção das instalações em Årdal. No final de 2006 - exatamente o mesmo ano em que a Hydro decidiu fechar partes da usina em Årdal - uma equipe de campo da Hydro chegou ao Qatar para avaliar as possibilidades de produção de alumínio com as autoridades do país. ${ }^{89}$ Os trabalhos de construção tiveram início em 2008, com envolvimento direito de 56.000 trabalhadores de mais de 200 empresas, num total de 90 milhões de horas de trabalho no canteiro de obras. ${ }^{\circ} \mathrm{Em} 12$ de abril de 2010, o emir do Qatar, acompanhado pelo príncipe herdeiro da Noruega, Haakon, inaugurou a recém-concluída maior usina de alumínio jamais construída. ${ }^{91}$

A desindustrialização também parece destinada a desempenhar um papel no futuro de Porto Trombetas. Novas minas estão planejadas para Paragominas (pela Companhia Vale do Rio Doce) e para Juriti Velho (pela Alcoa), também na Amazônia. ${ }^{22}$ Quando a mina do Trombetas foi criada, previa-se que as atividades mineradoras durariam 150 anos. Estas estimativas otimistas foram revisadas

85 Acessar http://hydro.no/no/Pressesenter/Nyheter/Arkiv/2006/Mars/15461.

86 FRøLAND, Hans Otto e KARLSEN, Asbjørn. Innledning. Globalisering gjennom et århundre. Langsiktige trekk ved norsk aluminiumindustri. In: Johan HENDEN, Hans Otto FRØLAND e Asbjørn KARLSEN (orgs.). Globalisering gjennom et århundre: Norsk aluminiumindustri 1908-2008. Bergen: Fagbokforlaget, 2008, p. 7-32 (22).

87 Acessar http://no.wikipedia.org/wiki/\%C3\%85rdal. Como Johnson coloca, "A competição vê-se sempre transformada pela política." JOHNSON, Introduction, p. 9.

88 JOHANSEN, Roald. Omstillingen i Årdal: Sluttrapport. Lysaker: Ifo-Institutt for Organisasjonsutvikling, 2008. BUKVE, Oddbjørn, GLOSVIK, Øyvind, MUNDAL, Harald, NESSE, Jon Gunnar, TRENGEREID, VERONIKA e Vebostad, Åge. Omstillingsprogrammet i Sogn og Fjordane: Resultat og erfaringar. Sogndal: Høgskolen i Sogn og Fjordane, 2009.

89 http://www.qatalum.com/en/About-Qatalum/. Nesse mesmo período, a produção de alumínio em Michigan e Sunndal, Noruega, também foi reduzida ou se encerrou. Ver http://www.hydro.com/no/Pressesenter/Nyheter/Arkiv/2009.

90 http://www.qatalum.com/en/Media-room/News/2010/Royal-inauguration-of-Qatalum-a-world-class-smelter.

91 http://www.qatalum.com/en/About-Qatalum. HASSAN, Nahla Abdalla. Living and Working Conditions of the Migrant Workers Hired to Construct the World's Largest Aluminium Plant at Qatalum, Qatar. Oslo: Oslo University College, 2009.

92 SWITKES. Foiling the Aluminium Industry, p. 6. 
recentemente e parece provável que o conglomerado multinacional de alumínio, que atualmente gere a mina, encerrará todas as atividades nos próximos vinte anos. Já que não existem outras atividades comerciais evidentes na área, a vila residencial criada pela cidade-empresa corre o risco de se tornar numa cidade fantasma. A mina projetada para Juriti Velho tem reservas de bauxita estimadas em 350 milhões de toneladas.

As comunidades do entorno do local de mineração sobreviviam tradicionalmente da extração sustentável de recursos da floresta e da pesca. Entraram com queixas do desflorestamento pela Alcoa e de ameaças por guardas armados que restringiram o acesso de membros da comunidade a uma área de 65.000 hectares que a Alcoa reivindica ser sua. Nos planos para a nova mina da Alcoa, 8.000 hectares deverão ser desflorestados. Líderes da comunidade de Juriti Velho manifestaram preocupação com as 1.800 famílias que vivem perto do Grande Lago (local proposto pela Alcoa para a mina e para a usina de alumínio) onde se encontram extensas áreas de floresta virgem e várias espécies ameaçadas de animais. Se o desflorestamento se espalhar, a área corre o risco de transformar-se num deserto. ${ }^{93}$ Todavia, neste caso a história não precisa necessariamente repetirse. O contexto político nacional na virada para o século XXI é muito diferente no Brasil de quando Porto Trombetas foi criada, bem como as possibilidades já comprovadas de mobilização de redes ambientalistas locais e internacionais. Em 2010, a Hydro comprou 30\% da companhia brasileira Vale do Rio Doce, a acionista majoritária da Paragominas, deste modo estabelecendo bases para laços futuros entre o Brasil e a Noruega nas cadeias produtivas transnacionais do alumínio.

Recebido em: 10/02/2014 Aprovado em: 15/04/2014 